\title{
Impacts of anthropogenic land-use change on populations of the Endangered Patagonian cypress Fitzroya cupressoides in southern Chile: implications for its conservation
}

\author{
James Rodríguez-Echeverry, Cristian Echeverría and Laura Nahuelhual
}

\begin{abstract}
Land-use change can have negative effects on threatened species by modifying their habitat and population dynamics. The habitat of the Endangered Patagonian cypress Fitzroya cupressoides (Mol.) Johnst. (Cupressaceae), a conifer endemic to the temperate forests of southern Chile and Argentina, has been transformed by land-use change and overexploitation. The impact of landuse change on the spatial pattern of $F$. cupressoides habitat from 1999 to 2011 was evaluated at the landscape level, using satellite images. Additionally, eight $20 \times 25 \mathrm{~m}$ plots were established in four populations to assess their status. In each plot the density of $F$. cupressoides and the species richness of the associated plant communities were recorded and analysed, together with spatial patterns at the population and community levels. The loss of potential F. cupressoides habitat was $46 \%$ from 1999 to 2011 (38-100\% for the four populations). The density of $F$. cupressoides was lowest in smaller habitat patches, where the number of plant species was higher and the matrix dominated by anthropogenic landuse. Land-use change was associated with a loss of potential habitat for F. cupressoides, and differences in the spatial patterns of habitat influenced the composition of remaining populations and communities. A landscape approach is recommended as a conservation planning strategy for $F$. cupressoides.
\end{abstract}

Keywords Anthropogenic processes, Chilean larch tree, Fitzroya cupressoides, habitat assessment, landscape change, Patagonian cypress, spatial patterns

To view supplementary material for this article, please visit http://dx.doi.org/So030605314000945

\footnotetext{
James Rodríguez-Echeverry (Corresponding author) and Cristian Echeverría Departamento de Manejo de Bosques y Medio Ambiente, Facultad de Ciencias Forestales, Universidad de Concepción, Chile

E-mail jhrodriguez@udec.cl

Laura Nahuelhual Facultad de Ciencias Agrarias, Instituto de Economía Agraria, Universidad Austral de Chile, Chile

Received 15 May 2014. Revision requested 30 September 2014.

Accepted 13 October 2014. First published online 30 March 2015.
}

\section{Introduction}

T and-use change can lead to habitat loss and fragmen1 tation, and these are two of the greatest threats to forest ecosystems (Noss, 2001; Baillie et al., 2004). Land-use change modifies connectivity, and patch density and area of forest (Lindenmayer \& Fischer, 2006). These changes can influence ecological attributes at the species and community levels, such as species richness and individual density (Laurance et al., 2000; Bustamante et al., 2003; Simonetti et al., 2006). Habitat loss and fragmentation can affect species' survival by reducing the quality and quantity of habitat available (Tomimatsu \& Ohara, 2003), both of which can alter the dynamics of a species' population. Such alteration could lead to local and global extinction of the most vulnerable species (Bennett, 2003).

The impact of land-use change on threatened species warrants investigation (Turner, 1989; Lindenmayer \& Fischer, 2006) to facilitate understanding of the way in which it can alter the composition and spatial configuration of the unique habitats on which threatened species depend, the influence of such alterations on species composition, the influence of the matrix, and the minimum buffer zone needed for management of the remaining interior habitats (Oliveira et al., 2004). Multi-scale studies (landscape, habitat and species) could provide valuable information for the conservation of threatened species (Vergara \& Simonetti, 2004).

Chilean temperate forest, which has been designated a hotspot for biodiversity conservation because of its high level of endemism (Myers et al., 2000), has experienced significant degradation, fragmentation and loss since 1985 as a result of land-use change (Echeverría et al., 2012). Consequently there have been significant changes in richness of plant (Echeverría et al., 2007) and bird species (Vergara \& Simonetti, 2004) and the spatial distribution of threatened species (Altamirano et al., 2007).

The Patagonian cypress Fitzroya cupressoides, an endemic and monotypic conifer of the temperate forests of southern Chile and Argentina, is categorized as Endangered on the IUCN Red List (Premoli et al., 2013). Individuals can live for $>3,600$ years, making it the second longest-lived species and thus of high scientific value (Lara 
\& Villalba, 1993). Since the arrival of Europeans in the south of Chile in 1850 F. cupressoides has been overexploited for its beautiful and decay-resistant wood. In Chile the species is found in the Coastal Range, the Andean Range and the Central Depression (Fraver et al., 1999). The species is known from 13 sites in the Central Depression, five containing small remnant populations and eight supporting scattered trees and saplings in a landscape transformed by human activities such as logging for firewood and expansion of pastureland for cattle grazing (Fraver et al., 1999). Genetic studies indicate that the F. cupressoides populations in the Central Depression are the most genetically distinct of the remaining populations in Chile and Argentina (Premoli et al., 2003), and represent ancient populations from the glacial era, from which the other populations are derived (Premoli et al., 2003).

Studies have focused on the reproductive biology, ecology and distribution of $F$. cupressoides (Armesto et al., 1992; Donoso et al., 1993; Fraver et al., 1999) but none have quantified the impact of land-use change on the spatial patterns of the species' habitat and examined the effect of habitat fragmentation and loss on population composition. This type of information is necessary to assess the current status of F. cupressoides populations, which may have been significantly altered in Chile.

We assessed the impact of land-use change on the spatial pattern of the forest landscape and the habitat of F. cupressoides in the Central Depression in southern Chile, and related changes in spatial pattern to the composition of four remaining populations. We hypothesize that humaninduced land-use change has substantially fragmented the remaining $F$. cupressoides habitat, resulting in reduced population density and variation in community composition.

\section{Study area}

The study area $\left(1,430 \mathrm{~km}^{2}\right)$ was defined by the distribution of four remaining populations of F. cupressoides in the Central Depression, Chile (Fraver et al., 1999), and by Landsat satellite images used to determine land-use change (Fig. 1). The area, characterized by a cold oceanic climate, has a maximum elevation of $200 \mathrm{~m}$, mean temperature of $11.5^{\circ} \mathrm{C}$ and annual rainfall of $1,912 \mathrm{~mm}$. The landscape in this area is dominated by patches of broad-leaved evergreen native forest of the Valdivian Rainforest.

\section{Methods}

Land-use change analyses were performed based on maps of land use, with $30 \times 30 \mathrm{~m}$ pixels, derived from Landsat satellite images for 1999 and 2011 (Echeverría et al., 2012). Land use was categorized as native forest, shrubland, wetland, grassland, forest plantations of exotic species or other uses (bare soil, urban areas and water bodies). Changes in spatial patterns of the forest landscape were assessed by determining the total area and number of patches of native forest, using FRAGSTATS v. 3.3 (McGarigal et al., 2002) and the Spatial Analyst extension for ArcGIS v. 9.3.1 (ESRI, Redlands, USA).

Four of the five known F. cupressoides populations in the Central Depression were included in the study; the fifth population was not assessed because access to information about it was limited. Spatially explicit information on the locations of populations was provided by Corporación Nacional Forestal.

The habitat of $F$. cupressoides in the Central Depression is characterized by poorly drained acidic soils ( $\mathrm{pH}$ of 5.0) known as ñadis (Fig. 1; FAOUNESCO, 1971), which means seasonal swamp in the indigenous Mapudungun language. These soils have a depth of $40-100 \mathrm{~cm}$, abundant humus, moss beds and coarse woody debris. The habitat of F. cupressoides is also characterized by a cold oceanic temperate climate, with annual mean temperature and rainfall of $11.5^{\circ} \mathrm{C}$ and $1,912 \mathrm{~mm}$, respectively, and by the presence of the following species of plants: Amomyrtus luma, Drimys winteri, Laureliopsis philippiana, Saxegothaea conspicua and Weinmannia trichosperma (IUCN, 2013).

A previous study in the same area revealed a relationship between F. cupressoides habitat and the interior of small patches of native forest (Fraver et al., 1999), which had a core area of $<_{3}$ ha and a buffer zone of $\geq_{137} \mathrm{~m}$. Fraver et al. (1999) reported that in the patches of native forest where edge effects (altered species composition, community structure and microclimate) occurred within $137 \mathrm{~m}$ of the patch edge, $F$. cupressoides populations were not present and only a few scattered $F$. cupressoides were recorded. Following the approach of Fraver et al. (1999) we defined the potential habitat of $F$. cupressoides as an area of native forest $<_{3}$ ha with a buffer zone of $\geq_{120} \mathrm{~m}$.

Areas of potential habitat for $F$. cupressoides were identified by analysing the core area and buffer zone of native forest patches, using the Land Change Modeler for Ecological Sustainability extension of IDRISI Andes (Clark Labs, Worcester, USA), which generated maps of potential habitat for the years 1999 and 2011. Changes in spatial patterns of potential habitat were evaluated by analysing the total area (ha) and number of potential habitat patches over time, using FRAGSTATS. Subsequently we identified the habitat patches that include the four remaining populations of F. cupressoides.

In 2011 we recorded the tree density (based on individuals with diameter at breast height $(\mathrm{DBH}) \geq_{5} \mathrm{~cm}$ and height $\geq_{2} \mathrm{~m}$ ) and level of regeneration (based on seedlings with $\mathrm{DBH}<{ }_{5} \mathrm{~cm}$ and/or height $<_{2} \mathrm{~m}$ ) in the four F. cupressoides 


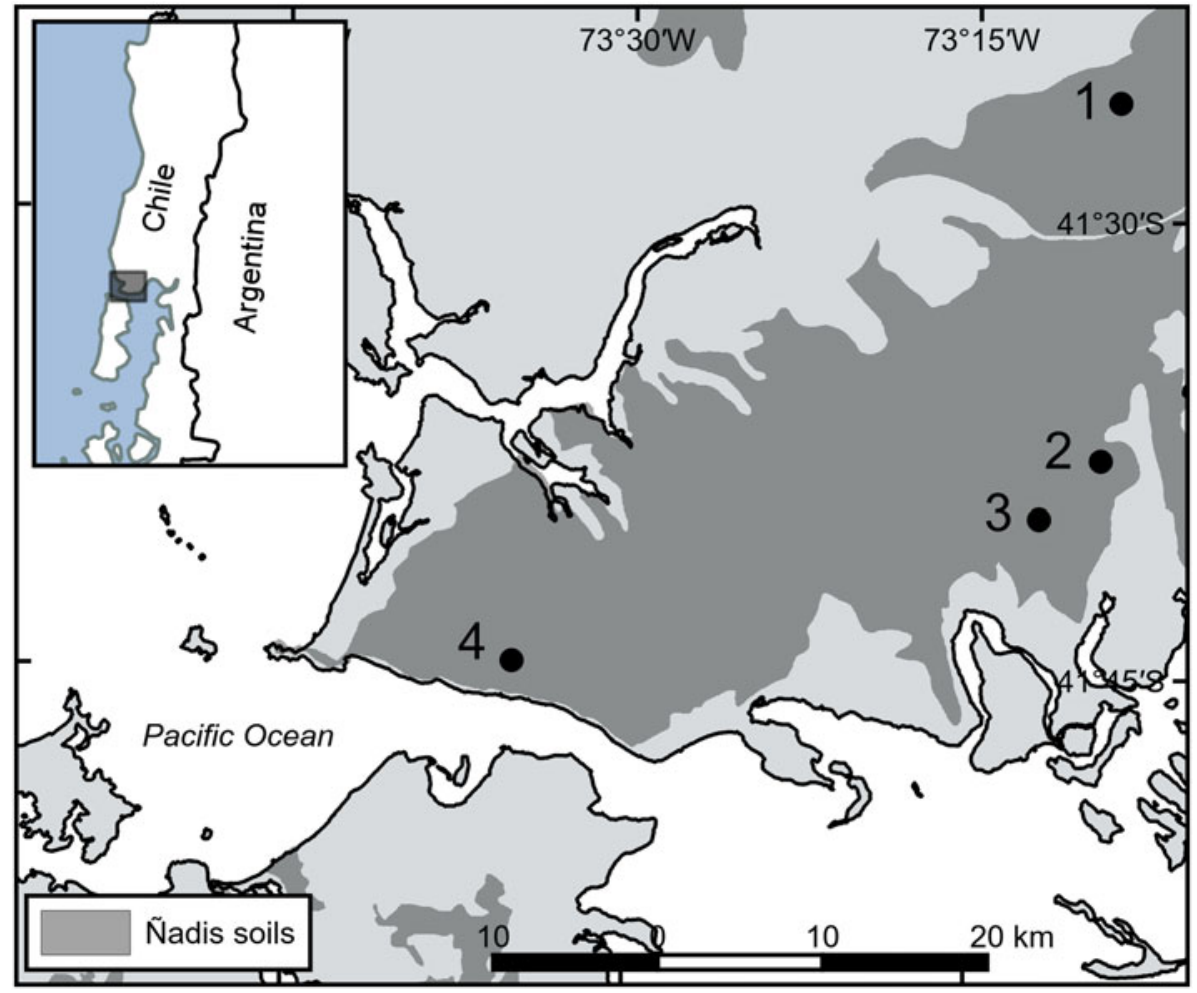

FIG. 1 Location of the four surveyed populations (1-4) of Fitzroya cupressoides in the Central Depression, Chile. The rectangle on the inset shows the location of the main map in Chile. populations (Fig. 1). We established two 20 x 25 m sampling plots randomly within each forest patch, taking into account the small size of the patches and the likelihood of edge effects. To facilitate data collection each plot was divided into $105 \times 10 \mathrm{~m}$ subplots, following the methods of Peet et al. (1996). We estimated the number of plant species present in native forest patches where $F$. cupressoides was present (Jiménez-Valverde \& Hortal, 2003). This information was analysed together with the area of the native forest patches where F. cupressoides was present, and the area of F. cupressoides habitat and the matrix that surrounded each $F$. cupressoides population.

\section{Results}

There was a loss of $18 \%$ of native forest in the study landscape from 1999 to 2011 (i.e. a mean annual loss of 1.6\%; Supplementary Fig. S1). In 1999 there were 9,478 patches of native forest, with a total area of 46,129 ha. The number of patches in $2011(22,446)$ was more than double that in 1999 , with a reduction in total area to 37,948 ha, and shrubland had become the dominant land cover type

There was a $46 \%$ loss in potential habitat for F. cupressoides from 1999 to 2011 (i.e. a mean annual loss of 5.1\%). In 1999 potential habitat for the species occurred in 112 patches of native forest (a total of 26,122 ha). In 2011 the number of patches had decreased to 36 and the total area to 14,076 ha. In 1999 the four F. cupressoides populations occurred in patches of 5-36 ha. In 2011 these patches were $0.4^{-27}$ ha (Table 1). Losses of $38,100,54$ and $79 \%$ of potential habitat were recorded over the entire study period for populations 1, 2, 3 and 4, respectively (Table 1).

There appeared to be a correlation between lower density of F. cupressoides seedlings and trees and greater loss of potential habitat (Table 1). In 2011 for the population with a loss of $38 \%$ of potential habitat we recorded a density of 2,270 trees per ha and regeneration of 4,340 trees per ha. For the population with a loss of $100 \%$ of potential habitat the density was 40 trees per ha and there was no regeneration (Table 1).

The populations of $F$. cupressoides for which greater loss of habitat was recorded were those surrounded by an anthropogenic matrix and were associated with plant communities with the greatest number of native and exotic species (Table 1). In 2011 the population for which a $38 \%$ loss of potential habitat was recorded was located in the largest patch of native forest ( $27 \mathrm{ha}$ ), embedded in a matrix dominated by native forest, and associated with a community with the lowest richness of exotic plant species (Table 1). The population for which a $100 \%$ loss of potential habitat was recorded was located in the smallest patch of native forest ( $0.4 \mathrm{ha}$ ), embedded in a matrix dominated by grassland, and associated with a community with the greatest richness of exotic plant species (Plantago truncata, Poa annua and Prunella vulgaris; Table 1). 


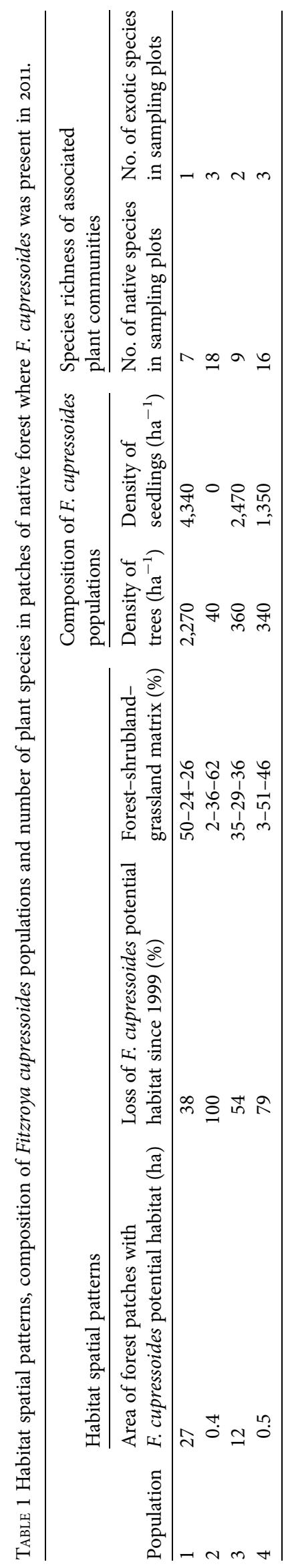

\section{Discussion}

\section{Changes in the forest landscape and Fitzroya} cupressoides habitat

Our results indicate there was a substantial loss of native forest in the study landscape from 1999 to 2011, although the annual rate of loss (1.6\%) was lower than that recorded for other hotspot landscapes that have been significantly transformed, such as the Maulino temperate forest in central Chile (4.5\% annual loss; Echeverría et al., 2006) and the tropical montane forest of Chiapas, Mexico (3.05\% annual loss; Cayuela et al., 2006). The loss of native forest area was associated with an increase in the number of patches, from 9,478 in 1999 to 22,400 in 2011, which is one of the main symptoms of fragmentation (Lindenmayer \& Fischer, 2006). The trend in fragmentation is similar to that reported for other temperate landscapes in Chile where threatened tree species occur (Bustamante \& Castor, 1998), as well as in tropical montane landscapes of conservation importance in Mexico (Cayuela et al., 2006). This trend of loss and fragmentation of native forest in the study landscape was associated with a significant loss (46\%) of potential habitat for F. cupressoides since the early 200os, with a decrease in the number of patches of potential habitat from 112 to 36 . If the current trajectory of loss and fragmentation of native forest continues, further losses of potential habitat for F. cupressoides can be expected.

\section{Changes at the population and community level in 2011}

We observed differences in habitat loss in each of the four $F$. cupressoides populations, associated with the densities of the populations. The smallest habitat patches had the lowest densities of F. cupressoides. Similar trends have been reported for other threatened plant species in Chile, such as Nothofagus alessandrii (Bustamante \& Castor, 1998) and Legrandia concinna (Altamirano et al., 2007), for various species of birds (Vergara \& Simonetti, 2004; Simonetti et al., 2006), and for some populations of insectivorous birds, primates and mammals in the Amazon rainforest (Laurance et al., 2000). A reduction in habitat size may decrease the density of F. cupressoides populations and thus increase the risk of extinction for this species.

Our results show that differences in the spatial patterns of habitat for the four F. cupressoides populations were associated with differences in the plant species richness of the associated communities. As the size of F. cupressoides habitat patches decreased, the number of native and exotic plant species increased. In the Chilean temperate forest a similar trend in community composition was reported for plants (Bustamante \& Grez, 1995), birds (Vergara \& Simonetti, 2004) and small mammals (Kelt, 2000). In boreal (Chávez \& Macdonald, 2010) and tropical areas (Trauernicht \& 
Ticktin, 2005) this change is less dramatic, perhaps because forest landscapes have not been transformed to the same extent. Other factors may also influence changes in the plant species richness of communities associated with patches of native forest where F. cupressoides occurs. The matrix may induce several types of abiotic changes at the edge of forest patches, resulting in the potential establishment and recruitment of generalist plant species (Bustamante et al., 2003). The combination of different patch sizes and matrix composition may have influenced the establishment of generalist native and exotic species in each community where $F$. $c u$ pressoides was present.

\section{Implications for conservation}

The Central Depression is located in a landscape that has been subjected to constant anthropogenic pressure (Torrejón et al., 2011). From the 16th to the 19th century significant changes in the spatial patterns of native forest were caused mainly by extensive wood extraction (Torrejón et al., 2011), whereas since the 1970 s the greatest changes in the spatial patterns of native forests have been caused by commercial plantations and expansion of pastureland for cattle grazing (Echeverría et al., 2007, 2012). The landscape of the Central Depression is under increasing pressure from the cities of Puerto Montt and Puerto Varas (Fraver et al., 1999), and anthropogenic land use may result in further changes in the spatial patterns of native forest and F. cupressoides habitat (Armesto et al., 1992; Wilson et al., 2005).

Fitzroya cupressoides was listed in Appendix I of CITES in 1975 and declared a Natural Monument by the Chilean government in 1976. Our multi-scale study has shown a progressive and severe loss of native forest with $F$. cupressoides populations from 1999 to 2011. If habitat loss continues, the population density of $F$. cupressoides may decrease further, increasing the risk of extinction for the species. As a first step in conserving $F$. cupressoides we suggest a landscape approach, using the corridor-patch-matrix model (Lindenmayer \& Franklin, 2002), as a strategy for conservation planning. This is appropriate given the current configuration of the landscape, with native forest restricted to small patches sparsely distributed across the landscape. The main objective of the corridor-patch-matrix model is to maintain the quality and quantity of patches of native forest through management of the matrix (Lindenmayer \& Franklin, 2002). The condition of the matrix may be more important in determining the survival of the species than the isolation of patches (Lindenmayer \& Franklin, 2002). In the study landscape the management of the matrix should focus on sensitive buffer areas that improve the connectivity between forest patches and increase the ability of the matrix to support $F$. cupressoides populations. We recommend that this strategy be complemented with land-use planning focused on sustainable production practices such as agroforestry. The design and implementation of such a strategy requires identification and evaluation of sensitive buffer areas and their connectivity. Moreover, this strategy must be supported by a framework of environmental policies.

We recommend that the Chilean government expands the country's protected areas to conserve F. cupressoides populations and promote conservation of the species. At present there is only one protected F. cupressoides population in the Central Depression, which is the Monumento Natural Lahuen Nadi. We also recommend strengthening the existing restoration programmes for F. cupressoides, and developing new programmes, to improve the quality of habitats for F. cupressoides. These programmes could include patches of native forest that are potential habitat for the species, monitoring to assess the viability and success of conservation efforts, and investment of capital. Researchers from the Universidad Austral de Chile, land owners, and Corporación Nacional Forestal are already participating in restoration programmes (Premoli et al., 2013) but the conservation of $F$. cupressoides also requires the commitment and active participation of the Chilean government and the general community.

\section{Acknowledgements}

We thank FONDECYT project 1085077, CONAF, Alberto Hernández, Natalia Medina, Víctor Sandoval, and Laboratorio de Ecología de Paisaje of the Universidad de Concepción. We also thank the Ministry of Education of Chile for a MECESUP scholarship.

\section{References}

Altamirano, A., Echeverría, C. \& Lara, A. (2007) Efecto de la fragmentación forestal sobre la estructura vegetacional de las poblaciones amenazadas de Legrandia concinna (Myrtaceae) del centro-sur de Chile. Revista Chilena de Historia Natural, 80, $27-42$.

Armesto, J., Smith-Ramirez, C., León, P. \& Arroyo, M. (1992) Biodiversidad y conservación del bosque templado en Chile. Ambiente y Desarrollo, 8, 19-24.

Baillie, J.E.M., Hilton-Taylor, C. \& Stuart, S.N. (2004) 2004 IUCN Red List of Threatened Species: A Global Species Assessment. IUCN, Gland, Switzerland.

Bennett, A.F. (2003) Linkages in the Landscape: The Role of Corridors and Connectivity in Wildlife Conservation. IUCN, Gland, Switzerland, and Cambridge, UK.

Bustamante, R.O. \& Castor, C. (1998) The decline of an endangered temperate ecosystem: the ruil (Nothofagus alessandrii) forest in central Chile. Biodiversity \& Conservation, 7, 1607-1626.

Bustamante, R.O. \& Grez, A.A. (1995) Consecuencias ecológicas de la fragmentación de los bosques nativos. Ambiente y Desarrollo, 11, 58-63.

Bustamante, R.O., Serey, I.A. \& Pickett, S.T.A. (2003) Forest fragmentation, plant regeneration and invasion processes across 
edges in central Chile. In How Landscapes Change: Human Disturbance and Ecosystem Fragmentation in the Americas (eds G.A. Bradshaw \& P.A. Marquet), pp. 145-16o. Springer-Verlag, Berlin, Germany.

Cayuela, L., Rey Benayas, J.M. \& Echeverría, C. (2006) Clearance and fragmentation of tropical montane forests in the Highlands of Chiapas, Mexico (1975-2000). Forest Ecology and Management, 226, 208-218.

ChÁvez, V. \& Macdonald, S.E. (2010) The influence of canopy patch mosaics on understory plant community composition in boreal mixedwood forest. Forest Ecology and Management, 259, 1067-1075.

CITES (2014) Convention on International Trade in Endangered Species of Wild Fauna and Flora. Appendices I, II and III. Http:// cites.org/eng/app/appendices.php [accessed 16 December 2014].

Donoso, C., Sandoval, V., Grez, R. \& Rodríguez, J. (1993) Dynamics of Fitzroya cupressoides forests in southern Chile. Journal of Vegetation Science, 4, 303-312.

Echeverría, C., Coomes, D., Salas, J.M., Rey Benayas, J., Lara, A. \& Newton, A. (2006) Rapid deforestation and fragmentation of Chilean temperate forests. Biological Conservation, 130, 481-494.

Echeverría, C., Newton, A., Lara, A., Rey Benayas, J.M. \& Coomes, D.A. (2007) Impacts of forest fragmentation on species composition and forest structure in the temperate landscape of southern Chile. Global Ecology and Biogeography, 16, 426-439.

Echeverría, C., Newton, A., Nahuelhual, L., Coomes, D. \& Rey BENAYAS, J.M. (2012) How landscapes change: integration of spatial patterns and human processes in temperate landscapes of southern Chile. Applied Geography, 32, 822-831.

FAO-UNESCO (1971) Soil Map of the World. Volume IV: South America. UNESCO, Paris, France.

Fraver, S., González, M.E., Silla, F., Lara, A. \& Gardner, M. (1999) Composition and structure of remnant Fitzroya cupressoides forests of southern Chile's Central Depression. Journal of the Torrey Botanical Society, 126, 49-57.

IUCN (2013) IUCN Red List of Threatened Species v. 2013.2. Http:// www.iucnredlist.org [accessed 5 December 2013].

Jiménez-Valverde, A. \& Hortal, J. (2003) Las curvas de acumulación de especies y la necesidad de evaluar la calidad de los inventarios biológicos. Revista Ibérica de Aracnología, $8,151-161$.

Kelt, D.A. (2000) Small mammal communities in rainforest fragments in Central Southern Chile. Biological Conservation, 92, $345-358$.

Lara, A. \& Villalba, R. (1993) A 3620-year temperature record from Fitzroya cupressoides tree rings in southern South America. Science, 260, 1104-1106.

Laurance, W.F., Vasconcelos, H.L. \& Lovejoy, T.E. (2000) Forest loss and fragmentation in the Amazon: implications for wildlife conservation. Oryx, 34, 39-45.

Lindenmayer, D.B. \& Fischer, J. (2006) Habitat Fragmentation and Landscape Change. An Ecological and Conservation Synthesis. Island Press, Washington, DC, USA.

Lindenmayer, D.B. \& Franklin, J.F. (2002) Conserving Forest Biodiversity: A Comprehensive Multiscaled Approach. Island Press, Washington, DC, USA.

McGarigal, K., Cushman, S.A., Neel, M.C. \& Ene, E. (2002) FRAGSTATS: Spatial Pattern Analysis Program for Categorical
Maps. Http://www.umass.edu/landeco/research/fragstats/fragstats. html [accessed 28 September 2013].

Myers, N., Mittermeier, R.A., Mittermeier, C.G., Da Fonseca, G.A.B. \& KENT, J. (2000) Biodiversity hotspots for conservation priorities. Nature, 403, 853-858.

Noss, R.F. (2001) Forest fragmentation in the Southern Rocky Mountains. Landscape Ecology, 16, 371-372.

Oliveira, M.A., Grillo, A.S. \& Tabarelli, M. (2004) Forest edge in the Brazilian Atlantic forest: drastic changes in tree species assemblages. Oryx, 38, 389-394.

Peet, R.K., Wentworth, T.R., Duncan, R. \& White, P.S. (1996) North Carolina Vegetation Survey Protocol: A Flexible, Multipurpose Method for Recording Vegetation Composition and Structure (version 2.o). University of North Carolina, Chapel Hill, USA.

Premoli, A., Quiroga, P., Souto, C. \& Gardner, M. (2013) Fitzroya cupressoides. In IUCN Red List of Threatened Species v. 2013.2. Http:// www.iucnredlist.org [accessed 10 December 2013].

Premoli, A., Vergara, R., Souto, C., Lara, A. \& Newton, A. (2003) Lowland valleys shelter the ancient conifer Fitzroya cupressoides in the Central Depression of southern Chile. Journal of the Royal Society of New Zealand, 33, 623-631.

Simonetti, J.A., Grez, A.A. \& Bustamante, R.O. (2006) Interacciones y procesos en el bosque maulino fragmentado. In Biodiversidad en ambientes fragmentados de Chile: patrones $y$ procesos a diferentes escalas (eds A.A. Grez, J.A. Simonetti \& R. O. Bustamante), pp. 99-114. Editorial Universitaria, Santiago, Chile.

Tomimatsu, H. \& Ohara, M. (2003) Genetic diversity and local population structure of fragmented populations of Trillium camschatcense (Trilliaceae). Biological Conservation, 109, 249-258.

Torrejón, F., Cisternas, M., Alvial, I. \& Torres, L. (2011) Consecuencias de la tala maderera colonial en los bosques de alerce de Chiloé, sur de Chile (siglos XVI-XIX). Magallania, 39, 75-95.

Trauernicht, C. \& Ticktin, T. (2005) The effects of non-timber forest product cultivation on the plant community structure and composition of a humid tropical forest in southern Mexico. Forest Ecology and Management, 219, 269-278.

Turner, M.G. (1989) Landscape ecology: the effect of pattern on process. Annual Review of Ecology and Systematics, 20, 171-197.

Vergara, P.M. \& Simonetti, J.A. (2004) Avian responses to fragmentation of the Maulino Forest in central Chile. Oryx, 38, 383-388.

Wilson, K., Newton, A., Echeverría, C., Weston, C. \& Burgman, M. (2005) A vulnerability analysis of the temperate forests of south central Chile. Biological Conservation, 122, 9-21.

\section{Biographical sketches}

James Rodríguez-Echeverry is a biologist interested in landscape ecology, ecological restoration and conservation. His research focuses on global change, threatened species, biodiversity and ecosystem services in the landscapes of Latin America. CRISTIAN ECHEVERRí is a forester interested in landscape ecology and conservation. His research focuses on threatened species, landscape change and ecological restoration of degraded forests in Latin America. Laura Nahuelhual is an agronomist interested in the economics of natural resources and rural development. Her research focuses on assessment and economic valuation of ecosystem services in Latin America. 